\title{
Structural, electrical and optical properties of copper-doped zinc oxide films deposited by spray pyrolysis
}

\section{(Propriedades estruturais, elétricas e óticas de filmes de óxido de zinco dopados com cobre depositados por spray-pirólise)}

\author{
J.S. C. Licurgo ${ }^{1 *}$, G. R. de Almeida Neto ${ }^{2}$, H. R. Paes Junior ${ }^{l}$ \\ ${ }^{1}$ Universidade Estadual do Norte Fluminense Darcy Ribeiro, Advanced Materials Laboratory, \\ Av. Alberto Lamego 2000, 28013-602, Campos dos Goytacazes, RJ, Brazil \\ ${ }^{2}$ Federal University of São Carlos, Graduate Program in Materials Science and Engineering, \\ S. Carlos, SP, Brazil
}

\begin{abstract}
The effect of copper doping on structural, electrical, and optical properties of zinc oxide films was evaluated. Copper-doped films $(\mathrm{ZnO}: \mathrm{Cu})$ were successfully deposited on a glass substrate by spray pyrolysis at doping levels of $0,2.5$, and 7.5 at $\%$ ( $\mathrm{ZnO}, \mathrm{ZC} 2.5$, ZC7.5). All films were polycrystalline, single-phase with $\mathrm{ZnO}$ hexagonal wurtzite structure. The films presented nanostructured crystallites, from 36.7 to $38.2 \mathrm{~nm}$. Cu doping increased the electrical conductivity of the $\mathrm{ZnO}$ films; this change was proportional to the $\mathrm{Cu}$ concentration. The films presented high optical transmittance of $70-80 \%$ in the visible wavelength. The energy gap decreased upon $\mathrm{Cu}$ doping. The photoluminescence spectrum of all films displayed an intense ultraviolet emission and a weaker blue emission. The emissions shifted to lower wavelengths with increasing dopant concentrations. ZC7.5 presented the most promising properties for an application as transparent conducting oxide: intense optical transmittance and UV photoluminescence, also the lowest electrical resistivity.
\end{abstract}

Keywords: copper-doped zinc oxide films, spray pyrolysis, luminescence, transparent conducting oxide.

\section{Resumo}

O efeito da dopagem com cobre nas propriedades estruturais, elétricas e óticas de filmes de óxido de zinco foi avaliado. Filmes dopados com cobre ( $\mathrm{ZnO}: \mathrm{Cu}$ ) foram depositados com sucesso em um substrato de vidro por spray-pirólise com concentração de dopante de 0, 2,5 e 7,5 \%at (ZnO, ZC2.5, ZC7.5). Todos os filmes foram policristalinos, com fase wurtzita hexagonal do ZnO. Os filmes apresentaram cristalitos nanoestruturados de 36,7 a 38,2 $\mathrm{nm}$. A dopagem de cobre aumentou a condutividade elétrica dos filmes de ZnO; essa mudança foi proporcional ao teor de dopante. Os filmes apresentaram elevada transmitância ótica de 70-80\% na região do espectro de luz visível. O gap ótico decresceu com a dopagem com Cu. Para todos os filmes o espectro de fotoluminescência apresentou emissão ultravioleta intensa e uma emissão azul mais fraca. As emissões se deslocaram para menores comprimentos de onda para maiores concentrações de dopante. ZC7.5 apresentou as propriedades mais promissoras para aplicações como óxido condutor transparente: transmitância ótica e fotoluminescência UV intensas, além da menor resistividade elétrica.

Palavras-chave: filmes de óxido de zinco dopados com cobre, spray-pirólise, luminescência, óxido condutor transparente.

\section{INTRODUCTION}

The progress of nanotechnology and nanoelectronics has attracted great interest in optoelectronic devices with multifunctional capacities. The increasing demand for low-cost and high-performance optoelectronic devices motivated the development of thin films of transparent conducting oxide (TCO). Since the first report regarding transparent oxide semiconductors by Bädeker in 1907 [1], the technological interest and value of these films have grown greatly. From this point on, deposition techniques

*julianasclicurgo@gmail.com

Dhttps://orcid.org/0000-0002-8238-5842 have been developed, and several electronic, optoelectronic, and mechanical applications have emerged. It is crucial that a TCO presents the lowest possible electrical resistivity and high optical transmittance (higher than $80 \%$ ) in the visible region [2]. Tin-doped indium oxide (ITO) is the TCO that has been widely used in the industry due to its excellent electrical and optical properties. However, indium is toxic, expensive, and scarce [3]. Other materials have been studied to replace ITO in this expanding market. Zinc oxide $(\mathrm{ZnO})$ is a candidate that has been receiving increasing attention.

$\mathrm{ZnO}$ is an II-IV semiconductor that has a high optical gap $(3.3 \mathrm{eV})$, excellent chemical and thermal stability, high excitation energy, intense luminescence at room temperature, non-toxicity, wide availability, and low-cost. 
This combination of favorable properties makes it a potential candidate for applications in optoelectronic devices, ultrasonic transducers, gas sensors, solar cells, and others [4-9]. The doping of $\mathrm{ZnO}$ is a form to enhance some of its properties. Transition metals such as $\mathrm{Mn}$ [8], $\mathrm{Cu}$ [8, 10-17], $\mathrm{Ag}$ [18], $\mathrm{Al}$ [19], Co [20], Ni [21], Ti [22], and V [23] have been explored as dopants for $\mathrm{ZnO}$. Copper is especially interesting due to similar ionic radius and electronic structure to $\mathrm{Zn}$, in addition to behaving as a luminescence activator through the creation of energy levels in the $\mathrm{ZnO}$ forbidden bands [8, 17, 24]. Mani and Rayappan [25] found superior $\mathrm{NH}_{3}$ sensing properties for $\mathrm{Cu}$-doped ZnO. Similarly, Shewale et al. [24] found that 4 wt $\%$ of $\mathrm{Cu}$ present the optimal performance for $\mathrm{H}_{2} \mathrm{~S}$ sensing. Liu et al. [26] studied nanopowders of $\mathrm{Cu}$-doped $\mathrm{ZnO}$ and observed intrinsic ferromagnetism at room temperature. Singhal et al. [27] found the solubility limit of $\mathrm{Cu}$ in $\mathrm{ZnO}$ to be 10 at $\%$ and observed DC electrical resistivity and activation energy decreasing with copper doping levels. Licurgo and Paes Junior [10] observed a decrease in band gap value with $\mathrm{Cu}$ doping.

$\mathrm{Cu}$-doped $\mathrm{ZnO}$ films can be produced by a great variety of deposition methods, as DC and RF magnetron sputtering [28], ice-bath assisted sonochemical method [11], sol-gel [29], sol-gel spin coating [30], pulsed laser deposition technique [31], and spray pyrolysis [10, 13]. Among the available techniques, spray pyrolysis is especially interesting since it is easily operated, low-cost, reproducible, and can be deposited on substrates with different geometries. In this paper, nanocrystalline thin films of $\mathrm{ZnO}$ and $\mathrm{Cu}$-doped $\mathrm{ZnO}$ were prepared on a glass substrate by spray pyrolysis technique. The films were comprehensively characterized in order to understand the effect of copper doping on $\mathrm{ZnO}$ properties. The morphological, structural, and electrical characterization were combined with the study of the optical absorption and photoluminescence behavior, providing valuable information on the doping process through this simple and cheap technique.

\section{MATERIALS AND METHODS}

Film deposition: $\mathrm{ZnO}$ film was prepared using the methodology described in the previous work of our research group [10]. Briefly, a precursor solution was prepared for the deposition of the $\mathrm{ZnO}$ films. A solution of $0.1 \mathrm{M}$ zinc acetate $\left[\mathrm{Zn}\left(\mathrm{CH}_{3} \mathrm{COO}\right)_{2} .2 \mathrm{H}_{2} \mathrm{O}\right.$, ACS grade, $98 \%$, Sigma Aldrich] was diluted in deionized water and isopropyl alcohol (ACS grade, $99.5 \%$, Isofar) in a 1:3 ratio (deionized water:alcohol). A solution of $0.02 \mathrm{M}$ copper chloride $\left(\mathrm{CuCl}_{2} \cdot 2 \mathrm{H}_{2} \mathrm{O}\right.$, ACS grade, $99 \%$, Sigma Aldrich) diluted in deionized water was used for doping the films with copper. Then, approximately $1 \mathrm{~mL}$ of acetic acid was added to the solution in order to neutralize the solution $\mathrm{pH}$. $\mathrm{ZnO}: \mathrm{Cu}$ solutions were prepared to yield a $\mathrm{Cu}$ doping of $0,2.5$, and 7.5 at\%, which were referred to as $\mathrm{ZnO}, \mathrm{ZC} 2.5$, and ZC7.5, respectively. Spray pyrolysis was the technique used for the film deposition. This technique consists of the atomization of a precursor solution, composed of ions of interest, on a pre-heated substrate. The droplets, when in contact with the heated substrate, decompose and react to form the desired chemical compounds. In this study, a homemade spray pyrolysis apparatus was used. The films were deposited for 30 min using a glass substrate temperature of $450{ }^{\circ} \mathrm{C}$, compressed air pressure of $1.5 \mathrm{kgf} / \mathrm{cm}^{2}$ and precursor solution flow rate of $1.5 \mathrm{~mL} / \mathrm{min}$.

Characterization of the films: morphological characterization of the films was performed in a laser confocal scanning microscope (Olympus, LEXT OLS 4000). The top surface micrographs were obtained formorphological analyses, and the film cross-section was analyzed in order to measure the film thickness. Structural characterization was performed by X-ray diffraction (XRD) technique in a diffractometer (Rigaku, Ultima IV). The following measurement parameters were used: $\mathrm{CuK} \alpha$ radiation (wavelength of $1.54 \AA$ ), step size of $0.05^{\circ}$, scanning speed of $1^{\circ} . \mathrm{min}^{-1}$, counting time of $3 \mathrm{~s}$, and scanning range from $20^{\circ}$ to $80^{\circ}(2 \theta)$. The crystallite size was calculated using the Debye-Scherrer equation for the most intense peak:

$$
\mathrm{D}_{\mathrm{hkl}}=\mathrm{K} \cdot \frac{\lambda}{\mathrm{B}_{\mathrm{hkl}} \cdot \cos \theta_{\mathrm{hkl}}}
$$

where $\mathrm{K}$ is a constant that depends on the crystallite geometry (assumed as 0.9 for spherical crystallite), $\lambda$ is the incident radiation wavelength $(1.5406 \AA), B_{h k l}$ is the full width at half maximum (FWHM), and $\theta$ is the Bragg's diffraction angle. The interplanar spacing $\mathrm{d}_{\text {hkl }}$ between (hkl) planes was calculated using Bragg's law [17]. The lattice parameters a and $\mathrm{c}$ of the films were calculated by [12]:

$$
\frac{1}{\mathrm{~d}_{\mathrm{hkl}}}=\frac{4}{3} \cdot\left(\frac{\mathrm{h}^{2}+\mathrm{h} \cdot \mathrm{k}+\mathrm{k}^{2}}{\mathrm{a}^{2}}\right)+\frac{\mathrm{l}^{2}}{\mathrm{c}^{2}}
$$

Electrical characterization was carried out by measuring the electrical conductivity $(\sigma)$ variation as a function of temperature $(\mathrm{T})$. The two-point probe method was used to obtain the film conductivity in a multimeter (Agilent, 3458). The activation energy for the electrical conduction process was calculated by:

$$
\beta=\frac{-E_{a}}{k}
$$

where $\beta$ is the slope of the $\ln \sigma$ vs. $\mathrm{T}^{-1} \times 10^{3}$ curve, $\mathrm{E}_{\mathrm{a}}(\mathrm{eV})$ is the activation energy, and $k$ is the Boltzmann constant. Sheet resistance was measured at room temperature using a 4-point head (Cascade Microtech, C4S-44/5S) in a multimeter (Agilent, 3458) with a home-made current source. From the sheet resistance, the electrical resistivity was calculated by:

$$
\mathrm{R}_{\mathrm{sh}}=\frac{\rho}{\mathrm{e}}
$$

where $\mathrm{R}_{\mathrm{sh}}$ is the sheet resistance $\left(\Omega \cdot \square^{-1}\right)$, and $\varrho$ is the electrical resistivity $(\Omega . \mathrm{cm})$. The variation of the film optical transmittance $\left(\mathrm{T}_{0}\right)$ as a function of the incident radiation wavelength $(\lambda)$ was the method used for the optical 
characterization of the films. The spectra were obtained using a spectrophotometer (Specord, M500) in the wavelength range from 300 to $850 \mathrm{~nm}$. The absorption coefficient $(\alpha)$ was calculated using Eq. E [32]. The optical gap of the films was obtained by the extrapolation of the linear portion of the $(\alpha . h v)^{2}$ vs. hv curve to the hv axis [32].

$$
\mathrm{a}=\frac{1}{\mathrm{e}} \cdot \ln \frac{1}{\mathrm{~T}_{0}}
$$

where $\alpha$ is the absorption coefficient, and $T_{0}$ is the optical transmittance. Photoluminescence measurements were performed in a spectrofluorophotometer (Shimadzu, RF5301PC). In this technique, light with the desired wavelength is directed to the sample to obtain the emission spectrum. The measurements were performed at an excitation wavelength of $325 \mathrm{~nm}$.

\section{RESULTS AND DISCUSSION}

Morphological characterization: most applications in the electronic and optoelectronics industry require films of high quality, with the lowest concentration of defects. The films produced in our study by spray pyrolysis were welladhered to the glass substrate and homogeneous. In Fig. 1, the top surface micrographs of the films are shown. There were no cracks or other types of defects on the surfaces. Also, they presented nanoscale grains, and there was no clear morphology difference between the film surfaces.
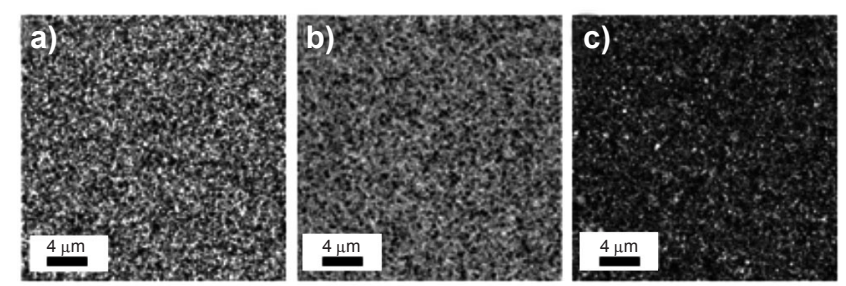

Figure 1: Laser confocal scanning microscope micrographs of the film top surfaces of: a) $\mathrm{ZnO}$; b) ZC2.5; and c) ZC7.5.

[Figura 1: Micrografias de microscópio de varredura confocal a laser das superfícies superiores dos filmes: a) ZnO; b) ZC2.5; e c) ZC7.5.]

Structural characterization: XRD diffractograms of the films are presented in Fig. 2. The identified peaks of $\mathrm{ZnO}$ and $\mathrm{Cu}$-doped $\mathrm{ZnO}$ matched the $\mathrm{ZnO}$ hexagonal wurtzite pattern (JCPDS \#36-1451). The doping of $\mathrm{ZnO}$ with $\mathrm{Cu}$ did not modify its structure. Furthermore, diffraction peaks associated with $\mathrm{CuO}$ or other $\mathrm{Cu}$ compounds were not identified. These findings suggested that $\mathrm{Cu}$ ions occupy substitutional sites into $\mathrm{ZnO}$ hexagonal structure. The films presented similar relative peak intensities; the peak related to the (002) plane was the most intense for all films, followed by the (101) (Fig. $2)$. This revealed a preferential crystal growth along the c-axis (002), which is perpendicular to the substrate surface. The relative intensity of the (002) peak $\left[\mathrm{I}_{002} /\left(\mathrm{I}_{002}+\mathrm{I}_{102}+\mathrm{I}_{101}\right)\right]$ was $0.6,0.6$ and 0.5 , for $\mathrm{ZnO}, \mathrm{ZC} 2.5$ and $\mathrm{ZC} 7.5$, respectively. In the literature, there is not a clear trend regarding the change of

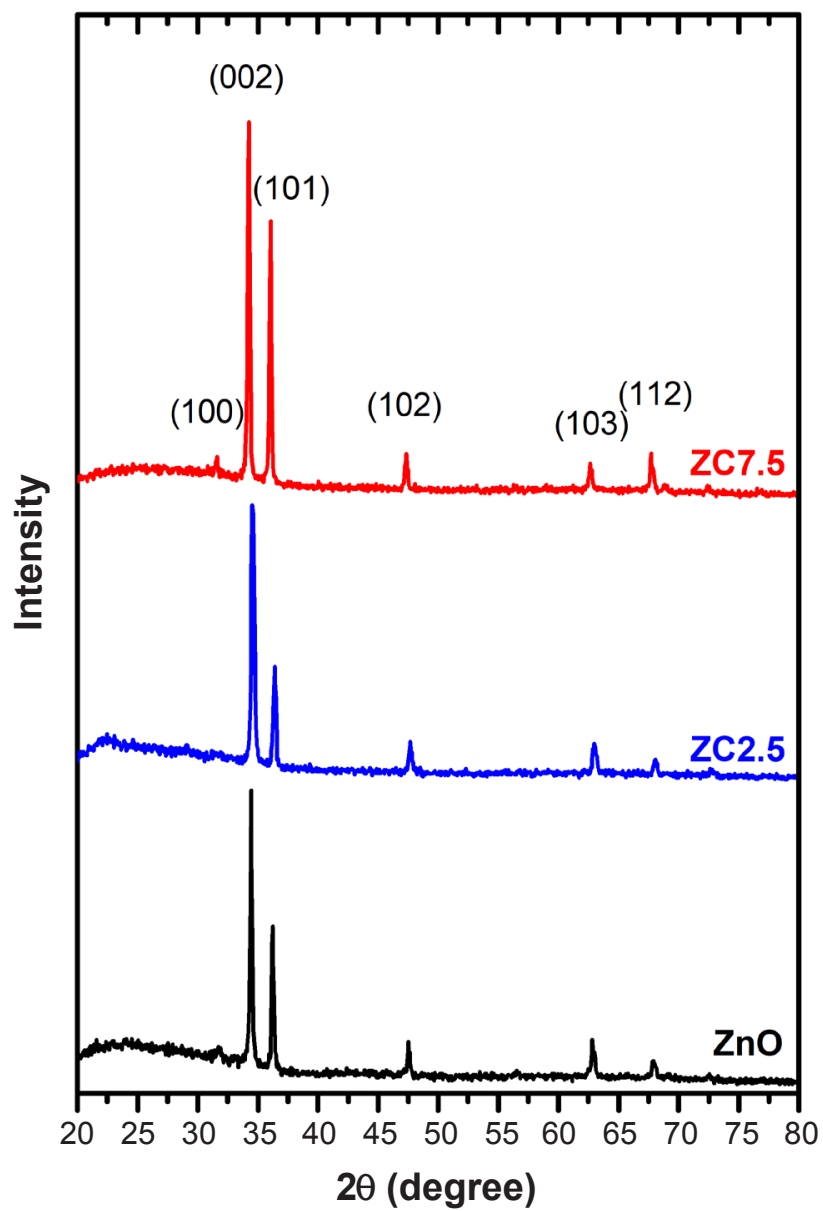

Figure 2: X-ray diffraction patterns of $\mathrm{ZnO}, \mathrm{ZC} 2.5$, and $\mathrm{ZC} 7.5$ films.

[Figura 2: Difratogramas de raios $X$ dos filmes $\mathrm{ZnO}, \mathrm{ZC} 2.5 e$ ZC7.5.]

$\mathrm{ZnO}$ (002) peak intensity upon $\mathrm{Cu}$ doping [8].

The calculated lattice parameters $(\mathrm{a}, \mathrm{c})$ and volume $(\mathrm{V})$ were similar to the values of the JCPDS 36-1451 (Table I). It was observed that ZC2.5 displayed slightly smaller lattice parameters than intrinsic $\mathrm{ZnO}$. However, for higher doping concentration (ZC7.5), it was observed that a and c increased, leading to an expanded unit cell volume. Othman et al. [11] observed similar behavior for $\mathrm{Cu}$-doped $\mathrm{ZnO}$ films produced by the sonochemical method. The unit cell volume reduced for $\mathrm{Cu}$ concentration below 5 at\%, and then a sudden increase for higher doping concentrations was observed. The doping process shifted the position of all $\mathrm{ZnO}$ diffraction peaks, shifting them to higher $2 \theta$ for $2.5 \mathrm{at} \% \mathrm{Cu}$, and to lower $2 \theta$ for 7.5 at $\% \mathrm{Cu}$. Regarding the most intense peak (002), the doping process shifted the peak position from a $2 \theta$ of $34.45^{\circ}$ to $34.55^{\circ}$ and $34.25^{\circ}$, for ZC2.5 and ZC7.5, respectively. The shift of the position of the peaks may be related to the incorporation of $\mathrm{Cu}$ into the $\mathrm{ZnO}$ structure. The ionic radii of $\mathrm{Cu}^{1+}, \mathrm{Cu}^{2+}$ and $\mathrm{Zn}^{2+}$ are $0.096,0.072$ and $0.074 \mathrm{~nm}$, respectively. Therefore, the valence state of the $\mathrm{Cu}$ ion that is doped into $\mathrm{ZnO}$ has an important role in the change of the c-axis (002). A higher diffraction angle relates to smaller interplanar spacing. Then, it is likely to believe 
Table I - Properties obtained from XRD data of $\mathrm{ZnO}, \mathrm{ZC} 2.5$, and ZC7.5 films.

[Tabela I - Propriedades obtidas por dados do DRX dos filmes ZnO, ZC2 .5 e ZC7.5.]

\begin{tabular}{ccccccc}
\hline Sample & $\begin{array}{c}\text { FWHM } \\
\beta_{(002)}\end{array}$ & $\begin{array}{c}\text { Crystallite } \\
\text { size }(\mathrm{nm})\end{array}$ & $\begin{array}{c}\mathrm{a} \\
(\AA)\end{array}$ & $\begin{array}{c}\mathrm{c} \\
(\AA)\end{array}$ & $\mathrm{c} / \mathrm{a}$ & $\begin{array}{c}\mathrm{V} \\
\left(\AA^{3}\right)\end{array}$ \\
\hline $\mathrm{ZnO}$ & 0.2238 & 37.1 & 3.25 & 5.21 & 1.60 & 47.74 \\
$\mathrm{ZC} 2.5$ & 0.2971 & 36.7 & 3.24 & 5.19 & 1.60 & 47.16 \\
$\mathrm{ZC} 7.5$ & 0.2178 & 38.2 & 3.27 & 5.24 & 1.60 & 48.49 \\
\hline
\end{tabular}

that $\mathrm{Cu}$ doping leads to substitution of $\mathrm{Zn}^{2+}$ predominantly by $\mathrm{Cu}^{2+}$. Othman et al. [11] observed the same behavior, where the (002) peak position shifted to a higher angle for $\mathrm{Cu}$ concentration of 4 at $\%$, and then it moved to a lower angle for 5 at $\%$. The authors believe that this shift was caused by the distortion of $\mathrm{ZnO}$ lattice by the introduction of larger concentrations of $\mathrm{Cu}$.

The crystallite size of the films was calculated by Scherrer formula using FWHM of $\mathrm{ZnO}$ (002) peak (Table I). All films presented a crystallite size smaller than $39 \mathrm{~nm}$. The doping process did not significantly change the $\mathrm{ZnO}$ film crystallite size. Nimbalkar and Patil [12] also found a negligible change of crystallite size upon $\mathrm{Cu}$ doping. Rahmani et al. [13] and Tarwal et al. [14] studied spray pyrolyzed films of $\mathrm{ZnO}$, and reported the crystallite size of $16-38$ and $22-42 \mathrm{~nm}$, respectively; these results agree with the obtained herein.

Electrical characterization: the influence of temperature on the electrical conductivity of the samples is presented in Fig. 3. A typical semiconductor behavior was observed for the films, where the electrical conductivity increased with temperature. The electrical conductivity of the intrinsic $\mathrm{ZnO}$ film was similar to that of $\mathrm{ZnO}$ nanorods, also obtained by spray pyrolysis [33]. Cu-doped samples presented higher electrical conductivity than that of intrinsic $\mathrm{ZnO}$. The increase was more pronounced for higher doping concentration. This result agreed with those reported in other studies [12, 15, 27, 34, 35], and this increase was likely due to a higher concentration of free carriers [15]. Other authors [34] suggested that $\mathrm{Cu}$ may reduce $\mathrm{ZnO}$, originating deficiency of oxygen, and producing nonstoichiometry in the sample. The activation energy for the electrical conduction process did not change significantly with $\mathrm{Cu}$ doping concentration (Table II).

The electrical resistivity of the films was obtained at room temperature by the 4-point probe method (Table II). The incorporation of the dopant was effective, decreasing the films' electrical resistivity. The incorporation of $\mathrm{Cu}$ into the $\mathrm{ZnO}$ host matrix occurred mainly in the +2 valence state by replacing $\mathrm{Zn}^{2+}$ sites, resulting in an increased concentration of free carriers, which was caused by the lower ionization potential of $\mathrm{Cu}$ atoms than that of Zn. In the doped films, the crystallite size slightly increased with the dopant concentration, which reduced the grain boundary scattering. These two behaviors provided an increment on the electrical conductivity of the doped films in comparison to the intrinsic film. Oxygen desorption performs an important role in the activation energy of the electrical
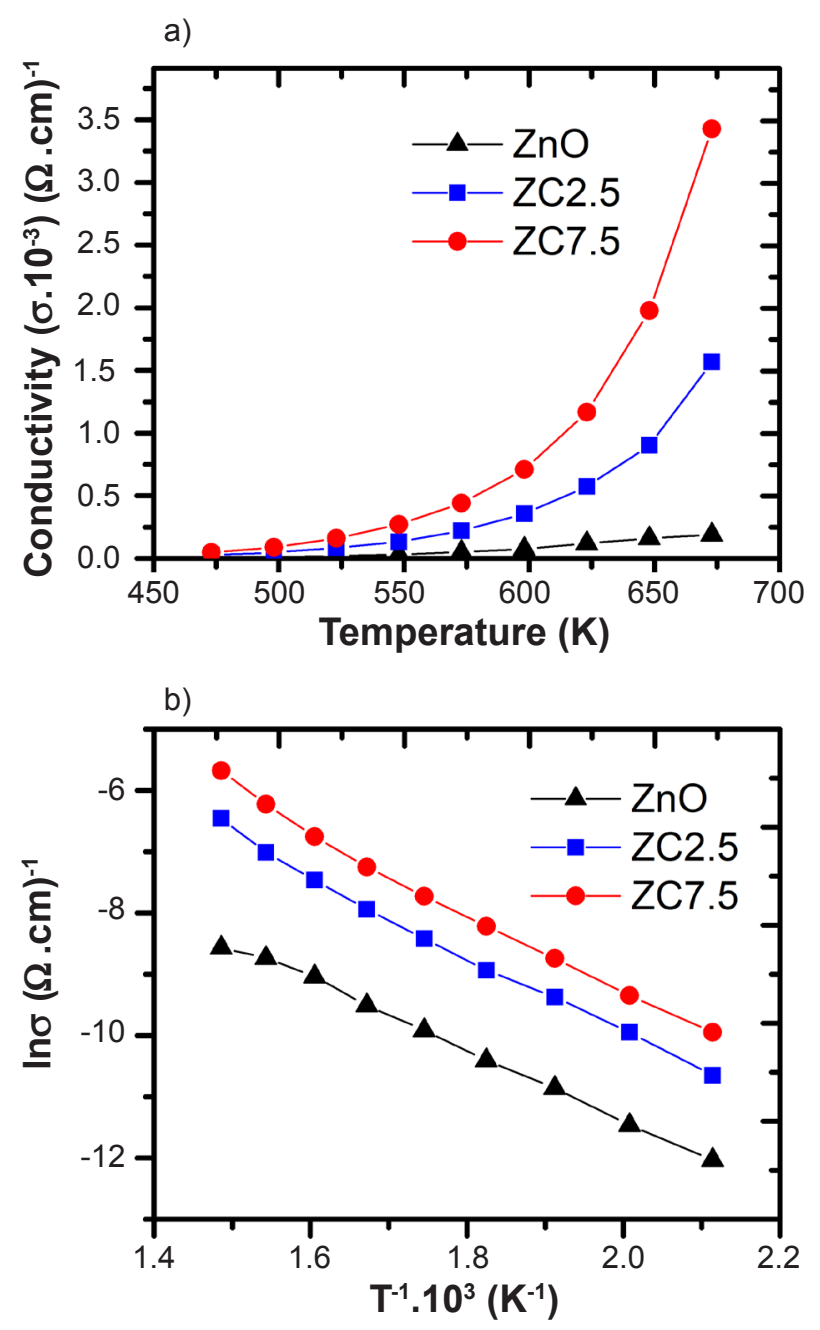

Figure 3: Curves of electrical conductivity as a function of temperature (a) and its natural logarithm as a function of the inverse of temperature (b) of $\mathrm{ZnO}, \mathrm{ZC} 2.5$, and ZC7.5 films.

[Figura 3: Curvas de condutividade elétrica em função da temperatura (a) e seu logaritmo natural em função do inverso da temperatura (b) dos filmes ZnO, ZC2.5 e ZC7.5.]

conduction process, as suggested in [36], indicating the presence of deep donor levels, from which the carriers jump to the conduction band by a thermally activated process. The values of electrical resistivity obtained in this study were lower than the reported for DC and radio frequency (RF) magnetron sputtered films [16, 28, 37, 38]. This indicates that high-quality films can be obtained using a cheaper and simpler deposition technique, spray pyrolysis. 
Table II - Properties obtained from the electrical and optical characterization of ZnO, ZC2.5, and ZC7.5 films.

[Tabela II - Propriedades obtidas por caracterizações elétricas e óticas dos filmes ZnO, ZC2.5 e ZC7.5.]

\begin{tabular}{ccccc}
\hline Sample & $\begin{array}{c}\text { Activation energy } \\
(\mathrm{eV})\end{array}$ & $\begin{array}{c}\text { Resistivity } \\
(\Omega . \mathrm{cm})\end{array}$ & $\begin{array}{c}\text { Absorption } \\
\text { coefficient }\left(\mathrm{cm}^{-1}\right)\end{array}$ & $\begin{array}{c}\text { Optical gap } \\
(\mathrm{eV})\end{array}$ \\
\hline $\mathrm{ZnO}$ & 0.50 & 6.58 & $6.2 \times 10^{2}$ & 3.27 \\
$\mathrm{ZC} 2.5$ & 0.53 & 5.84 & $9.2 \times 10^{2}$ & 3.18 \\
$\mathrm{ZC} 7.5$ & 0.54 & 2.93 & $1.1 \times 10^{3}$ & 3.24 \\
\hline
\end{tabular}

Optical characterization: the curves of optical transmittance of the $\mathrm{ZnO}: \mathrm{Cu}$ films are presented in Fig. 4. The films displayed intense optical transmittance within the visible spectrum. High transmittance in a large range of wavelengths can be useful for a variety of optical applications [39]. Films with low electrical resistivity are likely to present high optical quality due to low dispersion or absorption losses. Intrinsic $\mathrm{ZnO}$ film presented sharper absorption edge and high optical transmittance of approximately $80 \%$ in the wavelength range of 380 to 800 $\mathrm{nm}$ (Fig. 4). The optical transmittance of ZC2.5 and ZC7.5 films were smaller than that of $\mathrm{ZnO}$ from 380 to nearly $650 \mathrm{~nm}$. However, it still reached approximately $70 \%$ at a wavelength of $550 \mathrm{~nm}$ and continued to increase until $~ 80 \%$ at $800 \mathrm{~nm}$. A high transmittance is an important property for TCO applications, and it reveals the films' morphological homogeneity and crystal quality [33]. However, the lower optical transmittance for ZC2.5 and ZC7.5 may be due to the increase of absorbing centers with the incorporation of $\mathrm{Cu}$, consequently increasing the film light absorption capacity. Moreover, the decrease of transmittance can also be associated with the scattering of incident photons by the incorporation of copper at the substitutional or interstitial sites in the $\mathrm{ZnO}$ matrix. Similar results were found in [16, 17]. Tarwal et al. [14] observed a drop of transmittance to nearly $70 \%$ at $600 \mathrm{~nm}$ for a doping concentration of 5 and 10 at $\%$ of $\mathrm{Cu}$, which matches the values observed in our study. The authors observed that the doping of 20 at $\%$ of $\mathrm{Cu}$ decreases it, even more, reaching 50\% of transmittance [14].

The optical gap and absorption coefficient of the films, which was calculated at the wavelength of $550 \mathrm{~nm}$, are presented in Table II. Cu-doped films presented a greater absorption coefficient and a slightly smaller optical gap. The decrease in the optical gap can be explained by the optical gap of $\mathrm{CuO}(1.40 \mathrm{eV})$ being smaller than that of $\mathrm{ZnO}$ (3.37 $\mathrm{eV}$ ) and the difference of $\mathrm{Zn}$ and $\mathrm{Cu}$ electronegativities [14, 40]. It has also been proposed that this reduction is due to the hybridization of $3 \mathrm{~d}$ orbitals of $\mathrm{Cu}$ with $2 \mathrm{p}$ bands of $\mathrm{O}$ [41]. The trend found herein matches those of previously published studies [13, 14, 17, 25]. In order to study the absorption edge of the samples, the curves of the derivative of transmittance $(\mathrm{dT} / \mathrm{d} \lambda)$ versus wavelength of the samples were plotted (Fig. 4b). It was observed that all samples presented a sharp absorption edge, presenting a peak related to the optical band gap, which intensity is directly related to the optical gap values [42]. The optical gap obtained by this method matches closely that of the Tauc plot.

The photoluminescence spectra of $\mathrm{ZnO}$ and $\mathrm{Cu}$-doped $\mathrm{ZnO}$ films are presented in Fig. 5. ZnO film presented intense and weak UV emissions around $396 \mathrm{~nm}(3.13 \mathrm{eV})$
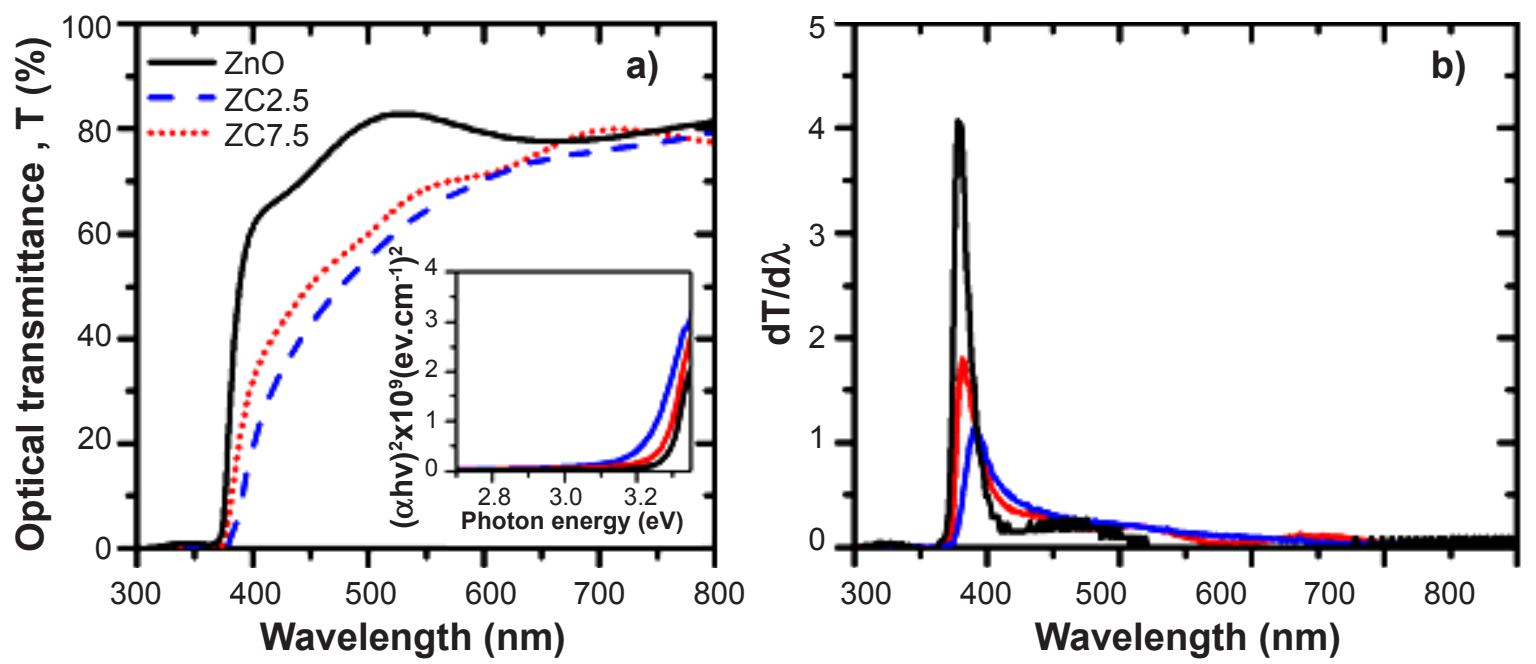

Figure 4: Optical transmittance as a function of wavelength and the inset of $(\alpha . h v)^{2}$ versus hv (a), and the curves of the derivative of transmittance (dT/d $\lambda$ ) versus wavelength (b) of the $\mathrm{ZnO}, \mathrm{ZC} 2.5$, and ZC7.5 films.

[Figura 4: Transmitância ótica em função do comprimento de onda e inserto de $(\alpha . h v)^{2}$ versus hv (a) e curvas de derivada de transmitância $(d T / d \lambda)$ versus comprimento de onda dos filmes $\mathrm{ZnO}, \mathrm{ZC} 2.5$ e ZC7.5.] 
and $361 \mathrm{~nm}(3.43 \mathrm{eV})$, respectively. This was related to the near-band edge (NBE) free exciton transition. Emission in the blue spectrum around $470 \mathrm{~nm}(2.64 \mathrm{eV})$ was also observed. It is likely that the blue emission is related to the recombination of trapped electrons at shallow bands of interstitial $\mathrm{Zn}$ with photo-generated holes [11, 43] and/ or the decay from $\mathrm{Zn}$ interstitial level to $\mathrm{Cu}^{+}$[29]. Spectra with similar characteristics were obtained in [40]. The photoluminescence intensity decreased upon Cu-doping, which indicated that a nonradiative recombination process, such as Auger, occurred in the samples [11]. Recombination centers tend to increase with higher doping concentration and structural defects [44]. Therefore, it is likely that the disappearance of the weaker NBE emission of the $\mathrm{ZnO}$ after $\mathrm{Cu}$ doping is due to the formation of $\mathrm{Cu}$ acceptor levels and the introduction of defect levels in the $\mathrm{ZnO}$ optical band gap, leading to increased nonradiative recombination processes [38]. Structural defects such as oxygen vacancies are known for increasing the green emission [16]; since there was no significant green emission, it is believed that the density of this defect was low [14]. With the incorporation of $\mathrm{Cu}$ in the $\mathrm{ZnO}$ matrix, all emission shifted to lower wavelengths; the shift was more expressive for increasing $\mathrm{Cu}$ content. The intense UV emission shifted to $395 \mathrm{~nm}(3.14 \mathrm{eV})$ and $391 \mathrm{~nm}(3.17 \mathrm{eV})$ for ZC2.5 and ZC7.5 films, respectively. Furthermore, the emission peaks of $\mathrm{Cu}$-doped films were broader than the peaks of intrinsic film.

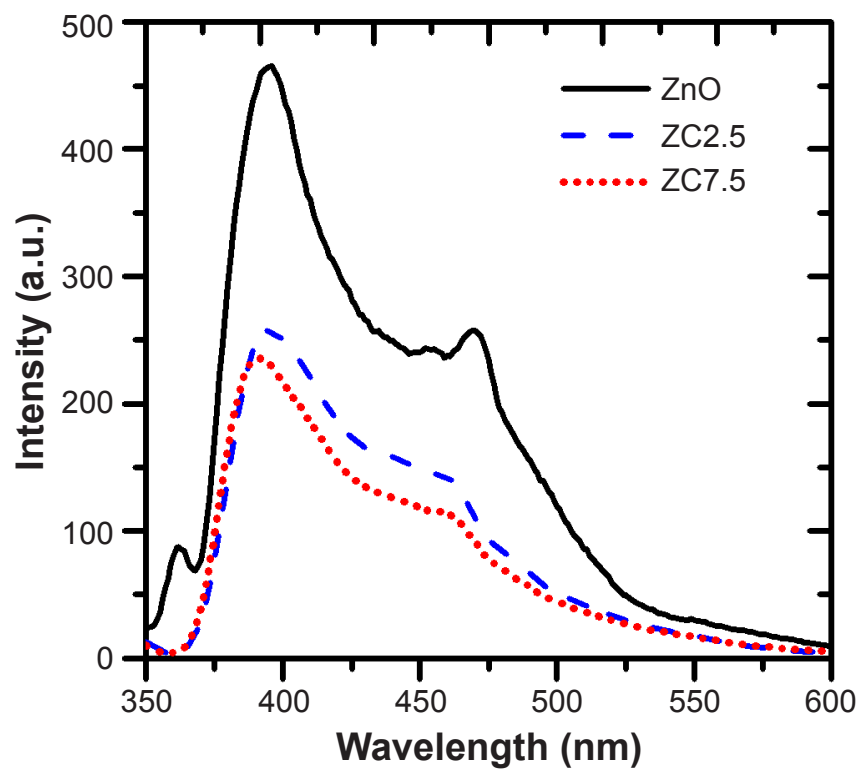

Figure 5: Photoluminescence spectrum of the $\mathrm{ZnO}, \mathrm{ZC} 2.5$, and ZC7.5 films.

[Figura 5: Espectro de fotoluminescência dos filmes $\mathrm{ZnO}, \mathrm{ZC2} .5$ e ZC7.5.]

\section{CONCLUSIONS}

Thin films were successfully prepared by the spray pyrolysis technique. The doping of $\mathrm{ZnO}$ with $\mathrm{Cu}$ changed the properties of the films significantly. On the XRD patterns, diffraction peaks related to $\mathrm{CuO}$ or other $\mathrm{Cu}$ compounds were not identified; all samples presented only the $\mathrm{ZnO}$ hexagonal wurtzite structure. This indicated that the doping was effective, where the $\mathrm{Cu}$ atoms occupied the substitutional sites of $\mathrm{Zn}$. The predominant valence state of $\mathrm{Cu}$ seemed to be $\mathrm{Cu}^{2+}$. The film crystallite size was not significantly affected by the doping process, ranging from 36.7 to $38.2 \mathrm{~nm}$. $\mathrm{ZnO}$ presented a typical semiconductor behavior, where electrical conductivity increased with temperature. The doping of $\mathrm{Cu}$ was beneficial for electrical conductivity. The $\mathrm{Cu}$-doped $\mathrm{ZnO}$ films presented higher electrical conductivity than that of $\mathrm{ZnO}$, and higher doping levels led to higher electrical conductivity. The optical transmittance results were satisfactory for the application as TCO (transparent conducting oxide), presenting intense transmittance of nearly $70-80 \%$ in the visible wavelength. Regarding the photoluminescence spectra, the films presented similar behavior, intense UV emission between 391 and 396 $\mathrm{nm}$, and weaker blue emission between 460 and $470 \mathrm{~nm}$. The results of this investigation showed that ZC7.5 ( $\mathrm{ZnO}$ $7.5 \mathrm{at} \% \mathrm{Cu}$ ) was the film that presented the most appropriate properties for TCO applications, combining higher electrical conductivity with desired photoluminescence spectrum and intense optical transmittance in the visible wavelength range.

\section{ACKNOWLEDGMENTS}

This study was financed in part by the Coordenação de Aperfeiçoamento de Pessoal de Nível Superior - Brasil (CAPES) - Finance Code 001. The authors would like to thank CNPq for J.S.C. Licurgo Masters Scholarship.

\section{REFERENCES}

[1] K. Bädeker, Ann. Phys. 327, 4 (1907) 749.

[2] B.G. Lewis, D.C. Paine, MRS Bull. 25, 8 (2000) 22.

[3] T. Minami, Semicond. Sci. Technol. 20, 4 (2005) S35.

[4] Y. Wang, M. Xu, J. Li, J. Ma, X. Wang, Z. Wei, X. Chu,

X. Fang, F. Jin, Surf. Coat. Technol. 330 (2017) 255.

[5] X.S. Zhou, C. Zhao, R. Hou, J. Zhang, K.J. Kirk, D. Hutson, Y.J. Guo, P.A. Hu, S.M. Peng, X.T. Zu, Y.Q. Fu, Ultrasonics 54, 7 (2014) 1991.

[6] L. Zhu, W. Zeng, Sens. Actuator A Phys. 267 (2017) 242.

[7] Z. Mo, Y. Huang, S. Lu, Y. Fu, X. Shen, H. He, Optik 149 (2017) 63.

[8] Z. Banu Bahşi, A.Y. Oral, Opt. Mater. 29, 6 (2007) 672.

[9] Ü. Özgür, Y.I. Alivov, C. Liu, A. Teke, M.A. Reshchikov, S. Doğan, V. Avrutin, S.-J. Cho, H. Morkoç, J. Appl. Phys. 98, 4 (2005) 41301.

[10] J.S.C. Licurgo, H.R. Paes Junior, Mater. Sci. Forum 930 (2018) 79.

[11] A.A. Othman, M.A. Ali, E.M.M. Ibrahim, M.A. Osman, J. Alloys Compd. 683 (2016) 399.

[12] A.R. Nimbalkar, M.G. Patil, Mater. Sci. Semicond. Process. 71 (2017) 332.

[13] M.B. Rahmani, S.H. Keshmiri, M. Shafiei, K. Latham, W. Wlodarski, J. du Plessis, K. Kalantar-Zadeh, Sens. Lett. 
7, 4 (2009) 621.

[14] N.L.L. Tarwal, K.V.V. Gurav, S.H.H. Mujawar, S.B.B. Sadale, K.W.W. Nam, W.R.R. Bae, A.V.V. Moholkar, J.H.H. Kim, P.S.S. Patil, J.H.H. Jang, Ceram. Int. 40, 6 (2014) 7669. [15] K. Omri, A. Bettaibi, K. Khirouni, L. El Mir, Phys. B Condens. Matter 537 (2018) 167.

[16] A. Sreedhar, J.H. Kwon, J. Yi, J.S. Kim, J.S. Gwag, Mater. Sci. Semicond. Process. 49 (2016) 8.

[17] A. Mhamdi, R. Mimouni, A. Amlouk, M. Amlouk, S. Belgacem, J. Alloys Compd. 610 (2014) 250.

[18] L. Duan, B. Lin, W. Zhang, S. Zhong, Z. Fu, Appl. Phys. Lett. 88, 23 (2006) 232110.

[19] P.P. Sahay, R.K. Nath, Sens. Actuators B Chem. 134, 2 (2008) 654.

[20] J. Hyun Kim, H. Kim, D. Kim, Y. Ihm, W. Kil Choo, J. Eur. Ceram. Soc. 24, 6 (2004) 1847.

[21] J.H. He, C.S. Lao, L.J. Chen, D. Davidovic, Z.L. Wang, J. Am. Chem. Soc. 127, 47 (2005) 16376.

[22] S.-S. Lin, J.-L. Huang, P. Šajgalik, Surf. Coat. Technol. 191, 2-3 (2005) 286.

[23] H. Saeki, H. Tabata, T. Kawai, Solid State Commun. 120, 11 (2001) 439.

[24] P.S. Shewale, V.B. Patil, S.W. Shin, J.H. Kim, M.D. Uplane, Sens. Actuators B Chem. 186 (2013) 226.

[25] G.K. Mani, J.B.B. Rayappan, J. Alloys Compd. 582 (2014) 414.

[26] H.L. Liu, J.H. Yang, Y.J. Zhang, Y.X. Wang, M.B. Wei, D.D. Wang, L.Y. Zhao, J.H. Lang, M. Gao, J. Mater. Sci. Mater. Electron. 20, 7 (2009) 628.

[27] S. Singhal, J. Kaur, T. Namgyal, R. Sharma, Physica B Condens. Matter 407, 8 (2012) 1223.

[28] D.R. Sahu, Mater. Sci. Eng. B 171, 1-3 (2010) 99.
[29] L. Xu, F. Xian, G. Zheng, M. Lai, Mater. Res. Bull. 99 (2018) 144.

[30] K.R. Gbashi, A.T. Salih, A.A. Najim, M.A.H. Muhi, J. Mater. Sci. Mater. Electron. 28, 20 (2017) 15089.

[31] Q.A. Drmosh, S.G. Rao, Z.H. Yamani, M.A. Gondal, Appl. Surf. Sci. 270 (2013) 104.

[32] J.I. Pankove, Optical processes in semiconductors, Dover Publ., New York (1971).

[33] E. Karaköse, H. Çolak, Energy 140 (2017) 92.

[34] H. Çolak, O. Türkoğlu, Mater. High Temp. 29, 4 (2012) 344.

[35] Y.S. Sonawane, K.G. Kanade, B.B. Kale, R.C. Aiyer, Mater. Res. Bull. 43, 10 (2008) 2719.

[36] S. Fujitsu, K. Koumoto, H. Yanagida, Y. Watanabe, H. Kawazoe, Jpn. J. Appl. Phys. 38, 1 3A (1999) 1534.

[37] M. Imran, R. Ahmad, N. Afzal, M. Rafique, Vacuum 165 (2019) 72.

[38] A.C. Saritha, M.R. Shijeesh, L.S. Vikas, R.R. Prabhu, M.K. Jayaraj, J. Phys. D Appl. Phys. 49, 29 (2016) 295105. [39] V. Ganesh, I.S. Yahia, S. AlFaify, M. Shkir, J. Phys. Chem. Solids 100 (2017) 115.

[40] F. Jamali-Sheini, R. Yousefi, Ceram. Int. 39, 4 (2013) 3715 .

[41] M. Ferhat, A. Zaoui, R. Ahuja, Appl. Phys. Lett. 94, 14 (2009) 142502.

[42] I.S. Yahia, A.A.M. Farag, M. Cavas, F. Yakuphanoglu, Superlattices Microstruct. 53 (2013) 63.

[43] H. Zeng, G. Duan, Y. Li, S. Yang, X. Xu, W. Cai, Adv. Funct. Mater. 20, 4 (2010) 561.

[44] Z.F. Liu, F.K. Shan, J.Y. Sohn, S.C. Kim, G.Y. Kim, Y.X. Li, J.Y. Sohn, J. Electroceramics 13, 1-3 (2004) 183.

(Rec. 22/10/2019, Rev. 06/02/2020, 16/03/2020, Ac. 20/03/2020) 